\title{
Guide to Pronunciation
}

Czech pronunciation is more straightforward than it appears. Unlike English, Czech spelling is mainly phonetic. The first syllable of most words is stressed, and the diacritical marks are easily learned.

a is between the English at and up

á is like the $a$ in bar

$\mathrm{c}$ is like the ts in hats

č is like the $c h$ in choice

d' is like the $d$ in duke

$\mathrm{e}$ is like the $e$ in bend

é is like the ea in bear

ě is like the ye in yet

ch is like the ch in Scottish loch

$\mathrm{i} / \mathrm{y}$ are like $i$ in if

$i / y$ are like the ee in beef

$\mathrm{j}$ is like the $y$ in yet (not like the $j$ in jet)

n is like the $n i$ in onion

ou is like oa in coat (not like ou in hound)

qu is pronounced $k v$

$r$ is rolled as in Scottish English

$\check{r}$ is like $r$ followed by $z$ (the name of the composer Dvoŕák sounds like

Dvorzhak)

š is like the sh in shop

$\mathrm{t}$ is like the $t$ in tube

$\mathrm{u}$ is like the oo in book

$\mathrm{u}$ is like the oo in soon

$\mathrm{w}$ is pronounced like the English $v$

$\mathrm{x}$ is like $k s$ in yaks (but between vowels it is hard $g z$ as in exit)

$\check{z}$ is like the $s$ in treasure 
[Duke University Press does not hold electronic rights to this image. To view it, please refer to the print version of this title.]

Saint Wenceslas (Václav) (ca. 907-35) has been venerated since the tenth century as the Czech "eternal ruler," who forever protects the country and its people. The bronze statue of the saint on horseback (by Josef Václav Myslbek, I898I9I3) dominates Wenceslas Square in the heart of Prague, capital of the Czech Republic. This photo was taken during the celebration of the New Year in 2005. Photo by Michal Kamaryt, used by permission of с̌тк. 